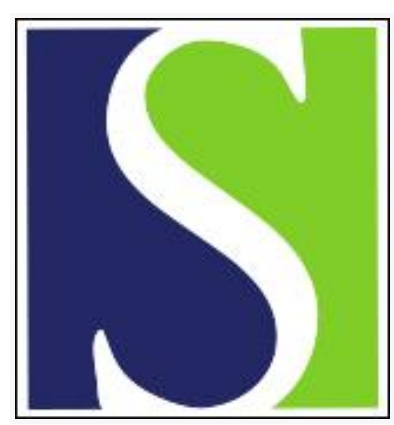

Scand J Work Environ Health 1995;21(5):382-390

https://doi.org/10.5271/sjweh.53

Issue date: Oct 1995

\title{
Visual dysfunction among styrene exposed workers
}

by Campagna D, Mergler D, Huel G, Bélanger S, Truchon G, Ostiguy C, Drolet D

The following article refers to this text: 2018;44(4):351-369

Key terms: color vision; contrast sensitivity; occupational exposure; styrene; visual symptom

This article in PubMed: www.ncbi.nlm.nih.gov/pubmed/8571095

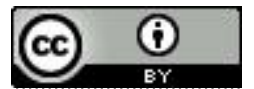




\title{
Visual dysfunction among styrene-exposed workers
}

\author{
by Dave Campagna, MSc, ${ }^{1,2}$ Donna Mergler, PhD, ${ }^{1}$ Guy Huel, PhD, ${ }^{1,2}$ Suzanne Bélanger, MSc, ${ }^{1}$ \\ Ginette Truchon, PhD, ${ }^{3}$ Claude Ostiguy, $P h D,{ }^{3}$ Daniel Drolet, $M S c^{3}$
}

\author{
Campagna D, Mergler D, Huel G, Bélanger S, Truchon G, Ostiguy C, Drolet D. Visual dysfunction among styrene- \\ exposed workers. Scand J Work Environ Health 1995;21:382-90.
}

\begin{abstract}
Objectives The present study was undertaken to examine the relation between visual functions and occupational exposure to styrene.

Methods A total of 128 workers ( $85 \%$ of the total population), from three glass-reinforced plastics plants in Canada, agreed to participate in the study. Environmental and biological measures were made on the day(s) prior to the assessment of near visual acuity (National Optical Visual Chart), chromatic discrimination (Lanthony D-15 desaturated panel), and near contrast sensitivity (Vistech 6000). The analyses were performed on 81 workers with near visual acuity of at least 1 min of arc at $0.5 \mathrm{~m}$.

Results The subjects were relatively young [29 (SD 8) years], with little seniority [5 (SD 4) years]. Styrene exposure for $8 \mathrm{~h}$ ranged from 6 to 937 (first quartile $21 \mathrm{mg} \cdot \mathrm{m}^{-3}$, third quartile $303 \mathrm{mg} \cdot \mathrm{m}^{-3}$ ), depending on the job site. The end-shift concentrations of urinary mandelic acid ranged from nondetectable to $1.90 \mathrm{mmol} \cdot \mathrm{mmol}$ creatinine $^{-1}$. Significant positive relations were found between the internal and external styrene exposure measurements and color vision loss adjusted for age, alcohol consumption, and seniority in a multiple regression analysis. The multiple regression analysis also showed that the end-shift concentration of urinary mandelic acid was inversely related to contrast sensitivity at 6 and 12 cycles $\cdot$ degree $^{-1}$. Logistic multiple regression models indicated that the end-shift concentration of urinary mandelic acid was related to the prevalences of blurred vision, tearing, and eye irritation.

Conclusions These findings suggest that there is a positive relation between styrene exposure and early color and contrast vision dysfunction.
\end{abstract}

Key ferms color vision, contrast sensitivity, occupational exposure, styrene, visual symptoms.

Styrene monomer (vinyl benzene, Chemical Abstract Service no $100-42-5$ ) is widely used in the manufacture of plastics and rubbers. The American National Institute for Occupational Safety and Health (NIOSH) estimates that approximately 30000 American workers are potentially exposed to styrene on a full-time basis in more than 1000 plants, and an additional 300000 may be periodically exposed (1). In the work environment styrene is absorbed primarily through the lungs with a small part coming through the skin $(2-3)$. This highly liposoluble solvent is readily distributed to the blood (4), fat tissues (4), and the membranes of every tissue and organ. Styrene is mainly metabolized in the liver. In humans, $2.6 \%$ of the absorbed styrene is excreted unchanged in the exhaled air or in the urine, $85 \%$ as urinary mandelic acid and $10 \%$ as urinary phenylglyoxylic acid (5). The end-shift concentration of urinary mandelic acid has been recommended for use as a biological indicator of styrene exposure (6).

Many investigations, most from the reinforced plastics industries, have demonstrated that styrene exposure is related to the prevalence of subjective neuropsychiatric complaints, including excessive fatigue, concentration and memory difficulties, and mood instability (79). In addition, abnormal electrocephalographic recordings $(10-12)$, a decrease in nerve conduction velocity (10), a reduction in psychomotor speed (13-16), auditory problems (17), and a high prevalence of acquired color vision loss (18-20) have been observed among styrene-exposed workers.

1 Centre pour l'étude des interactions biologiques entre la santé et l'environnement, CINBIOSE (Biological Interaction Between Health and Environment), University of Quebec in Montreal, Montréal, Canada.

2 National Institute of Health and Medical Research (INSERM) U169, Villejuif, France.

3 Quebec Institute for Research in Occupational Health and Safety (IRSST), Hygiene and Toxicology Program, Montreal, Canada.

Requests for reprints to: Mr Dave Campagna, INSERM, U169, 16 av Paul-Vaillant-Couturier, 94807 Villejuif Cedex, France. 
The neurochemical and structural bases of styrene neurotoxicity have not yet been fully explained. The neurotoxicity of this highly liposoluble solvent may partly result from lipid oxidation (21) that can modify the neuron membrane structure. Moreover, alteration of the membrane receptor may interfere with the propagation of nervous impulses. Neurotoxic effects of styrene exposure may also come from an effect on neurotransmitters since experimental studies show a diminution of striatal and tuberoinfundibulary dopamine in rats (22) and also in rabbits (23-24) exposed to styrene by inhalation. Moreover, the work of Arfini et al (25) and Mutti et al (26) suggest that the hyperprolactinemia noted among women exposed to styrene may result from a dopamine level reduction which could attenuate the dopaminergic modulation of prolactin secretion. Two hypotheses implicating a styrene metabolite are proposed to explain the dopamine reduction resulting from styrene exposure. The first one suggests that phenylglyoxylic acid is amined into phenylglycine, a phenyl ethylamine able to compete with dopamine for vesicular accumulation (23). The second (27) suggests the formation of a nonoperational neurotransmitter in a nonenzymatic condensation between dopamine and phenylglycine (Pictet-Spengler reaction) (26).

Dopamine is a central nervous system neurotransmitter and a neuromodulator of the light response in the retina. Dopaminergic modulation in the retina induces a decrease in electrical coupling between adjacent horizontal cells and a decrease in the light responsiveness of interneuronal horizontal inhibitor cells, which form the antagonistic surround response of the bipolar cells (28). Dopamine modulates the strength of the center-surround antagonism. An alteration of dopaminergic activity may alter the balance of the center and surround responses and thereby interfere with visual perception. However, dopamine depletion resulting from styrene exposure may lead to an electrical coupling between adjacent horizontal cells and an enlargement of the antagonistic surround and changes in visual perception.

Recently, an Italian study (18) showed chromatic discrimination loss in workers exposed to styrene in work with glass reinforced plastics when the workers were compared with their referents. Their findings suggest a possibility of a dose-effect relationship between styrene exposure and acquired color vision loss. Another study (19), carried out in France, showed color vision loss in styrene-exposed boat builders. In this study, chromatic discrimination capacity was measured with the Farnsworth-Munsell 100 Hue diagnostic test. These researchers also mentioned differences in contrast sensitivity at high frequencies (29).

The objective of the present study was to examine the relationship between internal and external parameters of styrene exposure and the visual functions chromatic discrimination and near visual contrast sensitivity.

\section{Subjects and methods}

\section{Subjects}

From a total of 151 persons employed in three Canadian reinforced plastics plants, $128(85.3 \%)$ volunteers participated in the study. Thirty-nine subjects were excluded for the following reasons: poor near visual acuity $(\mathrm{N}=11)$, solvent exposure other than in these plants $(\mathrm{N}=1)$, use of potentially ophthalmotoxic medication $(\mathrm{N}=2)$, diabetes, color blindness, ocular disorders and injuries $(\mathrm{N}=13)$, and incomplete biological exposure or sociodemographic data $(\mathrm{N}=12)$. In addition, since the neurotoxic effects associated with solvent exposure are generally encountered in chronic exposure, workers with less than six months of exposure in the plant $(\mathrm{N}=8)$ were also excluded from the present analysis. This time lapse was adopted empirically to keep a maximum of subjects while insuring a minimum of exposure.

The workers of this study included 79 men and 2 women with a visual resolution at $0.5 \mathrm{~m}$ superior to $1 \mathrm{~min}$ of arc. They were young [mean age 29 (SD 8, median 27) years] with little seniority [mean 5 (SD 4, median 4) years]. The average reported weekly alcohol intake, estimated from the number of bottles of beers, glasses of wine and glasses of hard alcohol was 160 (SD 181, median 100) g . week ${ }^{-1}$.

\section{Sociodemographic information and health symptoms}

Sociodemographic status, information about work conditions, and work history were obtained with a selfadministered questionnaire, which also included a symptom survey. In addition to the symptom questionnaire proposed in the book Prevention of Neurotoxic Illness in Working Populations (30) and questions from the Quebec Health Survey (31), visual symptoms such as eye irritation, tearing, and blurred vision were included.

\section{Exposure}

An environmental evaluation was done for styrene (table 1). Personal sampling for all workers was achieved with two personal passive dosimeters (3M 3500, 3M Canada Inc, Dorval, Quebec, Canada), each of them worn for approximately half of the 8 -h workshift. The analysis was carried out by gas chromatography with a flame ionization detector at the Quebec Institute for Research in Occupational Health and Safety (32).

The workers' urine was collected the day of the environmental evaluation for mandelic acid determination 
Table 1. Means and dispersion of the environmental and biological styrene exposure measurements.

\begin{tabular}{|c|c|c|c|c|c|}
\hline & $\begin{array}{l}\text { Arithmetic } \\
\text { mean }\end{array}$ & $\mathrm{SD}$ & $\begin{array}{c}\text { First } \\
\text { quartile }\end{array}$ & Median & $\begin{array}{l}\text { Third } \\
\text { quartile }\end{array}$ \\
\hline $\begin{array}{l}\text { Mandelic acida } \\
\text { (mmol } \cdot \mathrm{mmol} \\
\text { creatinine }{ }^{-1} \text { ) }\end{array}$ & 0.36 & 0.52 & 0.04 & 0.07 & 0.60 \\
\hline $\begin{array}{l}\text { Styrene }^{\mathrm{b}} \\
\left(\mathrm{mg} \cdot \mathrm{m}^{-3}\right)\end{array}$ & 205.78 & 262.35 & 19.75 & 42.99 & 378.49 \\
\hline
\end{tabular}

a End-shift urinary measurement.

b Mean environmental styrene sampled on an 8-h workshift

(table 1). End-shift urinary samples were collected by occupational health nurses, kept on ice, and sent to the Institute for analysis. Mandelic acid concentrations were analyzed by high-pressure liquid chromatography with ultraviolet detection (33), the results being corrected for urinary creatinine (34).

\section{Visual function assessment}

The testing of visual function was done on Saturday morning, at least $12 \mathrm{~h}$ after the last exposure. All visual functions, including near acuity, were examined monocularly in a darkened room, under standardized illumination provided by a "daylight" 1150-1x fluorescent lamp positioned $0.3 \mathrm{~m}$ above the caps. No time limit was imposed, and the participants with a perscription for eye glasses wore their own untinted glasses or contact lenses.
The workers were screened for adequate near visual acuity (minimal resolution of 1 min of arc at $0.5 \mathrm{~m}$ ) in each eye with the use of the National Optical Visual Chart placed at a distance of $0.4 \mathrm{~m}$.

Color vision was assessed with the Lanthony D-15 hue desaturated panel (Luneau Ophtalmique, Paris, France). This test is based on the ability to recombine a set of 15 desaturated color "caps" according to a definite chromatic sequence. Color vision loss was classified into type of acquired dyschromatopsia according to the classification of Verriest: loss in the blue-yellow or redgreen range. The subjects were classified as dyschromate if specific acquired loss was identified for at least one eye (35).

A quantitative evaluation was done by calculating the sum of the color differences of the caps placed adjacent to one another according to a formula developed by Bowman (36). The color confusion index was calculated by dividing the subjects' results by a perfect score. Thus one indicated a perfect score and values superior to one indicated increasing color vision loss. The color vision data have been presented as the mean color confusion index of the two eyes, the best score being the lower value and the worst being the higher score from the two eyes of each worker (table 2). Color vision loss was also classified into types of acquired dyschromatopsia: type III loss in the blue-yellow range, type II loss in the blueyellow and red-green type at the same time, and type I loss in the red-green range. A person was classified into

Table 2. Mean and dispersion of the visual function measurements.

\begin{tabular}{|c|c|c|c|c|c|}
\hline Score & $\begin{array}{c}\text { Arithmetic } \\
\text { mean }\end{array}$ & SD & $\begin{array}{c}\text { First } \\
\text { quartile }\end{array}$ & Median & $\begin{array}{l}\text { Third } \\
\text { quartile }\end{array}$ \\
\hline \multicolumn{6}{|c|}{ Color confusion index } \\
\hline $\begin{array}{l}\text { Mean } \\
\text { Best } \\
\text { Worst }\end{array}$ & $\begin{array}{l}1.14 \\
1.09 \\
1.20\end{array}$ & $\begin{array}{l}0.16 \\
0.12 \\
0.22\end{array}$ & $\begin{array}{l}1.05 \\
1.00 \\
1.06\end{array}$ & $\begin{array}{l}1.11 \\
1.05 \\
1.13\end{array}$ & $\begin{array}{l}1.23 \\
1.12 \\
1.30\end{array}$ \\
\hline \multicolumn{6}{|c|}{ Contrast sensitivity (cycles · degree ${ }^{-1}$ ) } \\
\hline \multicolumn{6}{|c|}{ Grating frequency 1.5} \\
\hline $\begin{array}{l}\text { Mean } \\
\text { Best } \\
\text { Worst }\end{array}$ & $\begin{array}{l}45.40 \\
48.76 \\
42.03\end{array}$ & $\begin{array}{l}19.19 \\
19.20 \\
13.91\end{array}$ & $\begin{array}{l}34.58 \\
34.57 \\
35.85\end{array}$ & $\begin{array}{l}39.14 \\
39.77 \\
36.18\end{array}$ & $\begin{array}{l}53.22 \\
65.65 \\
38.99\end{array}$ \\
\hline \multicolumn{6}{|c|}{ Grating frequency 3.0} \\
\hline $\begin{array}{l}\text { Mean } \\
\text { Best } \\
\text { Worst }\end{array}$ & $\begin{array}{l}89.24 \\
99.02 \\
79.46\end{array}$ & $\begin{array}{l}24.74 \\
35.69 \\
21.59\end{array}$ & $\begin{array}{l}81.56 \\
81.69 \\
80.43\end{array}$ & $\begin{array}{l}84.63 \\
86.36 \\
84.15\end{array}$ & $\begin{array}{l}90.79 \\
95.09 \\
85.68\end{array}$ \\
\hline \multicolumn{6}{|c|}{ Grating frequency 6.0} \\
\hline $\begin{array}{l}\text { Mean } \\
\text { Best } \\
\text { Worst }\end{array}$ & $\begin{array}{l}130.18 \\
140.26 \\
120.09\end{array}$ & $\begin{array}{l}40.03 \\
43.29 \\
42.11\end{array}$ & $\begin{array}{r}105.95 \\
120.29 \\
79.63\end{array}$ & $\begin{array}{l}124.59 \\
129.22 \\
121.23\end{array}$ & $\begin{array}{l}150.22 \\
179.07 \\
137.46\end{array}$ \\
\hline \multicolumn{6}{|c|}{ Grating frequency 12.0} \\
\hline $\begin{array}{l}\text { Mean } \\
\text { Best } \\
\text { Worst }\end{array}$ & $\begin{array}{l}85.08 \\
91.56 \\
78.59\end{array}$ & $\begin{array}{l}17.82 \\
18.68 \\
21.82\end{array}$ & $\begin{array}{l}79.96 \\
84.65 \\
65.73\end{array}$ & $\begin{array}{l}84.96 \\
88.23 \\
84.81\end{array}$ & $\begin{array}{l}92.51 \\
95.61 \\
90.72\end{array}$ \\
\hline \multicolumn{6}{|c|}{ Grating frequency 18.0} \\
\hline $\begin{array}{l}\text { Mean } \\
\text { Best } \\
\text { Worst }\end{array}$ & $\begin{array}{l}33.58 \\
38.33 \\
28.83\end{array}$ & $\begin{array}{l}12.20 \\
14.01 \\
12.43\end{array}$ & $\begin{array}{l}27.22 \\
32.76 \\
19.79\end{array}$ & $\begin{array}{l}33.32 \\
36.90 \\
29.39\end{array}$ & $\begin{array}{l}40.81 \\
44.03 \\
37.48\end{array}$ \\
\hline
\end{tabular}


one of the dyschromatopsia categories if he or she misplaced the caps by at least 2 . One cap inversion was classified as normal.

Near contrast sensitivity (table 2) was evaluated with the Vistech grating charts (VCTS 6000; Vistech Consultants Incorporated, Dayton, Ohio, United States), which were placed $0.4 \mathrm{~m}$ in front of the subject. This test is composed of three charts with 45 circles $0.013 \mathrm{~m}$ in diameter. The gratings in each circle are straight up, or 15 degrees to the left or right of vertical. Grating circles distributed on the testing chart in a specific order: the contrast diminishes horizontally from left to right (from 30 to $0 \%$, circle 1 to 9 ) and the grating frequency increases from top to bottom $(1.5,3,6,12$ and 18 cycles $\cdot$ degree $^{-1}$; line $\mathrm{A}$ to line $\mathrm{E}$ ). The tested person is required to identify the orientation of the grating on each circle for each frequency. The last circle of a specific frequency correctly identified corresponds to the perception threshold of the contrast sensitivity at this frequency (36). The contrast vision data are presented for each of the five spatial frequencies as the mean contrast sensitivity of the two eyes. The best score was the higher value and the worst was the lower value of the two eyes of each worker.

\section{Statistical analysis}

The normality of the variable distributions was evaluated and alcohol consumption, seniority, environmental styrene, and the end-shift concentration of urinary mandelic acid were log-transformed because of the skewed distributions. The relation between environmental styrene exposure and the end-shift concentration of urinary mandelic acid, according to the use of a chemical cartridge mask (user and nonuser), was studied in a covariance analysis. The correlation between the variables was determined with Spearman's coefficients (rs). Paired Student $\mathrm{t}$-tests were used to examine the difference between the best and worst eyes. Student t-tests were used to examine the difference between visual functions according to the dichotomous variable utilization, or no utilization of the chemical cartridge mask on the day of the exposure assessment. Multiple regression analyses were performed using the color confusion index or contrast sensitivity as the dependent variable and age, seniority, alcohol consumption, and the end-shift concentration of urinary mandelic acid as independent variables. Other multiple regression analyses were performed using the color confusion index or color sensitivity as the dependent variable and age, seniority, alcohol consumption, environmental styrene, and a dichotomic variable (utilization or no utilization of a chemical cartridge mask on the day of the exposure assessment) as independent variables. The prevalence of subjective symptoms and the qualitative analysis of dyschromatopsia were ob- tained by logistic multiple regression models. The dependent variable was one of the subjective symptoms or qualitative dyschromatopsia, and the independent variables were the ones already described. Statistical analyses were performed with the SAS statistical package (version 6, SAS Institute Inc, Cary, North Carolina, United States); the $95 \%$ confidence intervals were calculated.

\section{Results}

\section{Exposure}

The covariance analysis of exposure showed a significant difference between the two categories of mask user and nonuser. Figure 1 shows the relation between environmental styrene and the end-shift concentration of urinary mandelic acid. The regression line was drawn for those who did not use a chemical cartridge mask the day of exposure assessment $(\mathrm{N}=68, \mathrm{y}=0.0024 \mathrm{x}+0.0114$, $\mathrm{rs}=0.95, \mathrm{P}<0.001$ ).

\section{Styrene exposure and vision}

The differences between the best and the worst eyes were significantly different from zero $(\mathrm{P}<0.0001)$ for both the color confusion index and color sensitivity (table 2).

The relations between the measured visual functions and the styrene exposure measurements, after adjustment for age, alcohol consumption, and seniority, are presented in tables 3 and 4 . The results in table 3 reveal that both age and the end-shift concentration of urinary mandelic acid were positively related to the color confusion index, while contrast sensitivity (12 and $18 \mathrm{cy}$ cles $\cdot$ degree $^{-1}$ ) diminished with age and with the endshift concentration of urinary mandelic acid ( 6 and

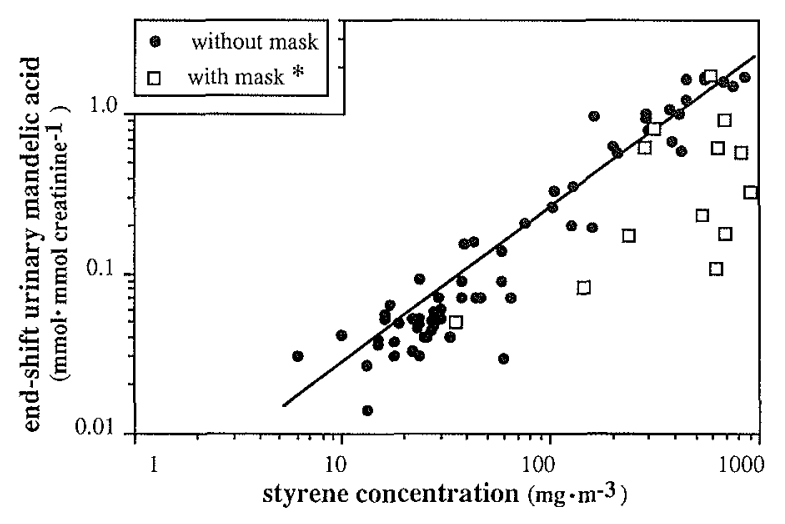

Figure 1. Relation between end-shift urinary mandelic acid excretion and the mean environmental styrene concentration sampled on a workshift ( $8 \mathrm{~h}) .\left(^{*}\right.$ data excluded from the regression line) 
Table 3. Multiple regression models between measured visual functions and end-shift urinary mandelic acid as adjusted for age, alcohol consumption, and seniority. ( $\beta=$ beta coefficient, $95 \% \mathrm{Cl}=95 \%$ confidence interval)

\begin{tabular}{|c|c|c|c|c|c|c|c|c|}
\hline \multirow[t]{2}{*}{ Score } & \multicolumn{2}{|r|}{$\begin{array}{c}\mathrm{Age} \\
\text { (years) }\end{array}$} & \multicolumn{2}{|c|}{$\begin{array}{c}\text { Alcohol } \\
\left(g \cdot \text { week }^{-1}\right)\end{array}$} & \multicolumn{2}{|c|}{$\begin{array}{l}\text { Seniority } \\
\text { (years) }\end{array}$} & \multicolumn{2}{|c|}{$\begin{array}{c}\text { Mandelic acida } \\
\left(\mathrm{mmol}^{-} \cdot \mathrm{mmol} \text { creatinine }{ }^{-1}\right) \\
\end{array}$} \\
\hline & $\beta$ & $95 \% \mathrm{Cl}$ & $\beta$ & $95 \% \mathrm{Cl}$ & $\beta$ & $95 \% \mathrm{Cl}$ & $\beta$ & $95 \% \mathrm{Cl}$ \\
\hline \multicolumn{9}{|c|}{ Golor confusion index } \\
\hline $\begin{array}{l}\text { Mean } \\
\text { Best } \\
\text { Worst }\end{array}$ & $\begin{array}{l}0.008 \\
0.005 \\
0.011\end{array}$ & $\begin{array}{l}0.003-0.013 \\
0.002-0.008 \\
0.005-0.179\end{array}$ & $\begin{array}{l}0.014 \\
0.012 \\
0.015\end{array}$ & $\begin{array}{l}-0.002-0.030 \\
0.0008-0.246 \\
-0.007-0.037\end{array}$ & $\begin{array}{r}0.002 \\
0.013 \\
-0.009\end{array}$ & $\begin{array}{l}-0.040-0.045 \\
-0.017-0.045 \\
-0.069-0.050\end{array}$ & $\begin{array}{l}0.158 \\
0.112 \\
0.203\end{array}$ & $\begin{array}{l}0.052-0.264 \\
0.034-0.191 \\
0.055-0.351\end{array}$ \\
\hline \multicolumn{9}{|c|}{$\begin{array}{l}\text { Contrast sensitivity } \\
\left(\text { cycles } \cdot \text { degree }^{-1} \text { ) }\right.\end{array}$} \\
\hline \multicolumn{9}{|c|}{ Grating frequency 1.5} \\
\hline $\begin{array}{l}\text { Mean } \\
\text { Best } \\
\text { Worst }\end{array}$ & $\begin{array}{l}-0.42 \\
-0.65 \\
-0.19\end{array}$ & $\begin{array}{l}-0.88-0.03 \\
-1.25--0.05 \\
-0.62-0.24\end{array}$ & $\begin{array}{l}-1.31 \\
-1.31 \\
-1.31\end{array}$ & $\begin{array}{l}-2.92-0.29 \\
-3.43-0.79 \\
-2.84-0.20\end{array}$ & $\begin{array}{r}1.08 \\
-0.28 \\
2.45\end{array}$ & $\begin{array}{l}-3.17-5.34 \\
-5.88-5.31 \\
-1.58-6.49\end{array}$ & $\begin{array}{l}-2.51 \\
-2.69 \\
-2.34\end{array}$ & $\begin{array}{l}-13.05-8.01 \\
-16.53-11.15 \\
-12.32-7.62\end{array}$ \\
\hline \multicolumn{9}{|c|}{ Grating frequency 3.0} \\
\hline $\begin{array}{l}\text { Mean } \\
\text { Best } \\
\text { Worst }\end{array}$ & $\begin{array}{l}-0.42 \\
-0.67 \\
-0.17\end{array}$ & $\begin{array}{l}-1.19-0.34 \\
-1.78-0.43 \\
-0.85-0.49\end{array}$ & $\begin{array}{r}-0.61 \\
0.03 \\
-1.26\end{array}$ & $\begin{array}{l}-3.32-2.09 \\
-3.86-3.94 \\
-3.64-1.11\end{array}$ & $\begin{array}{l}3.91 \\
6.43 \\
1.40\end{array}$ & $\begin{array}{l}-3.25-11.09 \\
-3.89-16.77 \\
-4.89-7.70\end{array}$ & $\begin{array}{l}-7.89 \\
-9.29 \\
-6.49\end{array}$ & $\begin{array}{l}-25.63-9.84 \\
-34.84-16.26 \\
-22.07-9.08\end{array}$ \\
\hline \multicolumn{9}{|c|}{ Grating frequency 6.0} \\
\hline $\begin{array}{l}\text { Mean } \\
\text { Best } \\
\text { Worst }\end{array}$ & $\begin{array}{l}-1.04 \\
-0.92 \\
-1.15\end{array}$ & $\begin{array}{l}-2.26-0.18 \\
-2.26-0.41 \\
-2.43-0.11\end{array}$ & $\begin{array}{r}0.35 \\
0.84 \\
-0.12\end{array}$ & $\begin{array}{l}-3.95-4.66 \\
-3.85-5.55 \\
-4.61-4.35\end{array}$ & $\begin{array}{l}11.35 \\
10.83 \\
11.87\end{array}$ & $\begin{array}{l}-0.05-22.76 \\
-1.61-23.29 \\
-0.01-23.74\end{array}$ & $\begin{array}{r}-19.18 \\
-8.49 \\
-29.88\end{array}$ & $\begin{array}{l}-47.39-9.01 \\
-39.27-22.29 \\
-59.25--0.51\end{array}$ \\
\hline \multicolumn{9}{|c|}{ Grating frequence 12.0} \\
\hline $\begin{array}{l}\text { Mean } \\
\text { Best } \\
\text { Worst }\end{array}$ & $\begin{array}{l}-0.79 \\
-0.65 \\
-0.93\end{array}$ & $\begin{array}{l}-1.34--0.24 \\
-1.23--0.07 \\
-1.60--0.27\end{array}$ & $\begin{array}{r}-0.65 \\
0.22 \\
-1.53\end{array}$ & $\begin{array}{l}-2.57-1.26 \\
-1.81-2.27 \\
-3.87-0.81\end{array}$ & $\begin{array}{l}3.23 \\
2.22 \\
4.24\end{array}$ & $\begin{array}{l}-1.84-8.32 \\
-3.18-7.64 \\
-1.94-10.44\end{array}$ & $\begin{array}{r}-12.46 \\
-8.43 \\
-16.50\end{array}$ & $\begin{array}{l}-25.04-0.11 \\
-21.81-4.94 \\
-31.82--1.19\end{array}$ \\
\hline \multicolumn{9}{|c|}{ Grating frequency 18.0} \\
\hline $\begin{array}{l}\text { Mean } \\
\text { Best } \\
\text { Worst }\end{array}$ & $\begin{array}{l}-0.77 \\
-0.89 \\
-0.66\end{array}$ & $\begin{array}{l}-1.15--0.40 \\
-1.32--0.46 \\
-1.04--0.27\end{array}$ & $\begin{array}{l}-0.25 \\
-0.14 \\
-0.36\end{array}$ & $\begin{array}{l}-1.57-1.06 \\
-1.66-1.37 \\
-1.70-0.90\end{array}$ & $\begin{array}{l}2.66 \\
2.26 \\
3.06\end{array}$ & $\begin{array}{l}-0.82-6.15 \\
-1.76-6.29 \\
-0.49-6.22\end{array}$ & $\begin{array}{l}-7.31 \\
-8.42 \\
-6.20\end{array}$ & $\begin{array}{l}-15.94-1.31 \\
-18.38-1.53 \\
-15.01-2.58\end{array}$ \\
\hline
\end{tabular}

a End-shift urinary measurement.

12 cycles $\cdot$ degree $\left.^{-1}\right)$. In addition, a positive relation was observed between alcohol consumption and the color confusion index of the best eye. The average index of both eyes and the scores calculated for the best and worst eyes generally showed the same relations.

Table 4 contains the results of the different multiple regression analyses computed with environmental styrene exposure. The relations between the vision scores and age and alcohol consumption were similar to those shown in table 3 . While the relations between the external exposure measurement and the color confusion index were always present, no significant relation with color sensitivity was observed. Moreover, the variable "utilization or no utilization of a chemical cartridge mask on the day of the exposure assessment" was also associated with the color confusion index. The positive relation observed between environmental styrene and the index scores became nonsignificant when the utilization of a chemical cartridge mask on the day of the exposure assessment was not taken into account. Moreover, excluding mask-user subjects from the analysis yielded results similar to those obtained when mask use was taken into account. The color and contrast vision of the workers who used a chemical cartridge mask on the day of the exposure assessment did not significantly differ from those of the workers who did not (not shown). Finally, the seniority of the workers in these plants was not related to the measured visual functions.

The quantitative evaluation, according to the type of dyschromatopsia, revealed that 25 of the 81 workers $(30.9 \%)$ presented profiles of acquired dyschromatopsia. There were 22 blue-yellow defects, 1 red-green defect, and 2 mixed defects. Six other workers also showed color vision loss with no specific axis. Results from the logistic multiple regression analysis of the relationship between acquired dyschromatopsia and styrene exposure (end-shift concentration of urinary mandelic acid or environmental styrene) after adjustment for age and alcohol consumption are presented in table 5. None of the odds ratios were significantly different from 1 when use of a chemical cartridge mask was taken into account in the model.

\section{Styrene exposure and reported symptoms}

The most frequently reported visual complaint was acute eye irritation $(N=35)$. Some workers also reported tearing $(\mathrm{N}=23)$ and blurred vision $(\mathrm{N}=31)$. Results from the logistic multiple regression analysis of the relationship between the worker's visual symptoms and styrene 
Table 4. Multiple regression models between the measured visual functions and styrene exposure, adjusted for age, alcohol consumption, seniority and utilization of a chemical cartridge mask. ( $\beta=$ beta coefficient, $95 \% \mathrm{Cl}=95 \%$ confidence interval)

\begin{tabular}{|c|c|c|c|c|c|c|c|c|c|c|}
\hline \multirow[t]{2}{*}{ Score } & \multicolumn{2}{|r|}{$\begin{array}{c}\text { Age } \\
\text { (years) }\end{array}$} & \multicolumn{2}{|r|}{$\begin{array}{c}\text { Alcohol } \\
\left(\mathrm{g} \cdot \text { week }^{-1}\right)\end{array}$} & \multicolumn{2}{|r|}{$\begin{array}{c}\text { Seniority } \\
\text { (years) }\end{array}$} & \multicolumn{2}{|r|}{$\begin{array}{l}\text { Mask user } \\
\text { (yes or no) }\end{array}$} & \multicolumn{2}{|r|}{$\begin{array}{c}\text { Styrene }^{b} \\
\left(\mathrm{mg} \cdot \mathrm{m}^{-3}\right)\end{array}$} \\
\hline & $\beta$ & $95 \% \mathrm{Cl}$ & $\beta$ & $95 \% \mathrm{Cl}$ & $\beta$ & $95 \% \mathrm{Cl}$ & $\beta$ & $95 \% \mathrm{Cl}$ & $\beta$ & $95 \% \mathrm{Cl}$ \\
\hline \multicolumn{11}{|c|}{ Color confusion index } \\
\hline $\begin{array}{l}\text { Mean } \\
\text { Best } \\
\text { Worst }\end{array}$ & $\begin{array}{l}0.007 \\
0.004 \\
0.010\end{array}$ & $\begin{array}{l}0.002-0.012 \\
0.001-0.008 \\
0.003-0.017\end{array}$ & $\begin{array}{l}0.016 \\
0.014 \\
0.018\end{array}$ & $\begin{array}{r}-0.0004-0.032 \\
0.002-0.026 \\
-0.005-0.041\end{array}$ & $\begin{array}{r}0.004 \\
0.014 \\
-0.006\end{array}$ & $\begin{array}{l}-0.039-0.047 \\
-0.017-0.046 \\
-0.067-0.054\end{array}$ & $\begin{array}{l}-0.115 \\
-0.091 \\
-0.139\end{array}$ & $\begin{array}{l}-0.225--0.006 \\
-0.171-0.011 \\
-0.293-0.013\end{array}$ & $\begin{array}{l}0.037 \\
0.028 \\
0.047\end{array}$ & $\begin{array}{l}0.009-0.066 \\
0.007-0.048 \\
0.007-0.087\end{array}$ \\
\hline \multicolumn{11}{|c|}{$\begin{array}{l}\text { Contrast sensitivity } \\
\text { (cycles } \cdot \text { degree }^{-1} \text { ) }\end{array}$} \\
\hline \multicolumn{11}{|c|}{ Grating frequency 1.5} \\
\hline $\begin{array}{l}\text { Mean } \\
\text { Best } \\
\text { Worst }\end{array}$ & $\begin{array}{l}-0.40 \\
-0.65 \\
-0.15\end{array}$ & $\begin{array}{l}-0.87-0.06 \\
-1.27--0.03 \\
-0.59-0.28\end{array}$ & $\begin{array}{l}-1.29 \\
-1.25 \\
-1.33\end{array}$ & $\begin{array}{l}-2.93-0.34 \\
-3.40-0.89 \\
-2.88-0.20\end{array}$ & $\begin{array}{r}0.77 \\
-0.89 \\
2.44\end{array}$ & $\begin{array}{l}-3.51-5.06 \\
-6.51-4.72 \\
-1.59-6.48\end{array}$ & $\begin{array}{r}0.21 \\
-3.70 \\
4.14\end{array}$ & $\begin{array}{r}-10.61-11.05 \\
-17.91-10.49 \\
-6.07-14.35\end{array}$ & $\begin{array}{r}0.08 \\
0.66 \\
-0.50\end{array}$ & $\begin{array}{l}-2.72-2.89 \\
-3.01-4.35 \\
-3.15-2.14\end{array}$ \\
\hline \multicolumn{11}{|c|}{ Grating frequency 3.0} \\
\hline $\begin{array}{l}\text { Mean } \\
\text { Best } \\
\text { Worst }\end{array}$ & $\begin{array}{l}-0.33 \\
-0.50 \\
-0.15\end{array}$ & $\begin{array}{l}-1.12-0.45 \\
-1.63-0.63 \\
-0.85-0.53\end{array}$ & $\begin{array}{r}-0.56 \\
0.22 \\
-1.35\end{array}$ & $\begin{array}{l}-3.32-2.19 \\
-3.73-4.18 \\
-3.77-1.06\end{array}$ & $\begin{array}{l}3.16 \\
4.98 \\
1.34\end{array}$ & $\begin{array}{l}-4.05-10.38 \\
-5.36-15.33 \\
-4.98-7.67\end{array}$ & $\begin{array}{l}5.63 \\
7.37 \\
3.89\end{array}$ & $\begin{array}{l}-12.61-23.88 \\
-18.78-33.52 \\
-12.10-19.90\end{array}$ & $\begin{array}{r}-0.12 \\
1.37 \\
-1.62\end{array}$ & $\begin{array}{l}-4.86-4.60 \\
-5.41-8.15 \\
-5.77-2.51\end{array}$ \\
\hline \multicolumn{11}{|c|}{ Grating frequency 6.0} \\
\hline $\begin{array}{l}\text { Mean } \\
\text { Best } \\
\text { Worst }\end{array}$ & $\begin{array}{l}-0.96 \\
-0.79 \\
-1.13\end{array}$ & $\begin{array}{l}-2.22-0.29 \\
-2.15-0.57 \\
-2.46-0.18\end{array}$ & $\begin{array}{r}0.19 \\
0.79 \\
-0.41\end{array}$ & $\begin{array}{l}-4.21-4.59 \\
-3.97-5.56 \\
-5.03-4.20\end{array}$ & $\begin{array}{l}10.62 \\
10.66 \\
10.59\end{array}$ & $\begin{array}{l}-0.90-22.15 \\
-1.80-23.13 \\
-1.48-22.66\end{array}$ & $\begin{array}{r}8.51 \\
13.44 \\
3.58\end{array}$ & $\begin{array}{l}-20.62-37.65 \\
-18.07-44.96 \\
-26.93-34.11\end{array}$ & $\begin{array}{l}-3.43 \\
-1.53 \\
-5.34\end{array}$ & $\begin{array}{r}-10.99-4.11 \\
-9.70-6.63 \\
-13.25-2.57\end{array}$ \\
\hline \multicolumn{11}{|c|}{ Grating frequence 12.0} \\
\hline $\begin{array}{l}\text { Mean } \\
\text { Best } \\
\text { Worst }\end{array}$ & $\begin{array}{l}-0.79 \\
-0.64 \\
-0.95\end{array}$ & $\begin{array}{l}-1.36--0.22 \\
-1.24--0.04 \\
-1.63-0.26\end{array}$ & $\begin{array}{r}-0.74 \\
0.21 \\
-1.71\end{array}$ & $\begin{array}{l}-2.72-1.22 \\
-1.87-2.31 \\
-4.11-0.67\end{array}$ & $\begin{array}{l}2.56 \\
1.49 \\
3.62\end{array}$ & $\begin{array}{l}-2.61-7.73 \\
-3.98-6.97 \\
-2.64-9.89\end{array}$ & $\begin{array}{r}-0.24 \\
-1.13 \\
0.64\end{array}$ & $\begin{array}{l}-13.31-12.83 \\
-14.98-12.72 \\
-15.20-16.49\end{array}$ & $\begin{array}{l}-1.92 \\
-0.61 \\
-3.23\end{array}$ & $\begin{array}{l}-5.31-1.46 \\
-4.20-2.98 \\
-7.34-0.87\end{array}$ \\
\hline \multicolumn{11}{|c|}{ Grating frequency 18.0} \\
\hline $\begin{array}{l}\text { Mean } \\
\text { Best } \\
\text { Worst }\end{array}$ & $\begin{array}{l}-0.72 \\
-0.81 \\
-0.63\end{array}$ & $\begin{array}{l}-1.10-0.34 \\
-1.25--0.37 \\
-1.02--0.24\end{array}$ & $\begin{array}{l}-0.36 \\
-0.25 \\
-0.47\end{array}$ & $\begin{array}{l}-1.69-0.96 \\
-1.78-1.27 \\
-1.83-0.88\end{array}$ & $\begin{array}{l}2.69 \\
2.25 \\
3.14\end{array}$ & $\begin{array}{l}-0.78-6.18 \\
-1.75-6.26 \\
-0.41-6.70\end{array}$ & $\begin{array}{r}7.47 \\
10.10 \\
4.84\end{array}$ & $\begin{array}{l}-1.33-16.28 \\
-0.02-20.23 \\
-4.14-13.84\end{array}$ & $\begin{array}{l}-1.96 \\
-2.07 \\
-1.85\end{array}$ & $\begin{array}{l}-4.24-0.31 \\
-4.69-0.55 \\
-4.19-0.47\end{array}$ \\
\hline
\end{tabular}

a Utilization or no utilization of a chemical cartridge mask on the day of the exposure assessment.

b Mean environmental styrene sampled on an 8-h workshift.

exposure (end-shift concentration of urinary mandelic acid or environmental styrene) after adjustment for age and alcohol consumption are presented in table 6 . For acute eye irritation, the odds ratios (OR) were significantly different from 1 with the end-shift concentration of urinary mandelic acid [OR 5.50, 95\% confidence interval $(95 \% \mathrm{CI}) 1.28-23.67]$ and for environmental styrene (OR $1.53,95 \%$ CI $1.09-2.14$ ). Tearing and blurred vision were also related to the end-shift urinary concentration of mandelic acid (OR 4.73, 95\% CI 1.07-20.87; OR $6.47,95 \%$ CI 1.43-29.28, respectively) but not with the environmental measurement. No change occurred in the results when use of a chemical cartridge mask was taken into account.

\section{Discussion}

This study showed that color vision loss increases with the 8-h styrene concentration at the job site for workers who do not use a chemical cartridge mask. Although the exposure measurements were made on a particular day, they were representative of daily exposure since there was no job rotation and production was continuous. Moreover, the participants had worked at the same job
Table 5. Acquired dyschromatopsia according to the styrene exposure measurement (end-shift urinary mandelic acid or environmental styrene), adjusted for age and alcohol consumption. $(\mathrm{OR}=$ odds ratio, $95 \% \mathrm{Cl}=95 \%$ confidence interval)

\begin{tabular}{|c|c|c|}
\hline & \multicolumn{2}{|c|}{ Dyschromatopsia } \\
\hline & $\mathrm{OR}$ & $95 \% \mathrm{Cl}$ \\
\hline Age (years) & 0.95 & $0.88-1.01$ \\
\hline Alcohol consumption $\left(g \cdot\right.$ week $\left.^{-1}\right)$ & 0.94 & $0.74-1.20$ \\
\hline Mandelic acida $\left(\mathrm{mmol}^{-}\right.$mmol creatinine $\left.\mathrm{e}^{-1}\right)$ & 0.32 & $0.08-1.35$ \\
\hline Age (years) & 0.95 & $0.89-1.01$ \\
\hline Alcohol consumption $\left(g \cdot\right.$ week $\left.^{-1}\right)$ & 0.94 & $0.74-1.20$ \\
\hline Styrene $\left(\mathrm{mg} \cdot \mathrm{m}^{-3}\right)$ & 0.92 & $0.66-1.29$ \\
\hline
\end{tabular}

a End-shift urinary measurement.

b Mean environmental styrene sampled on an 8-h workshift.

for an average of 3.7 years. When the workers who wore masks were included in the analysis, no relation was observed between the environmental styrene level and chromatic discrimination. This finding suggests that the effect was due to styrene absorbed through the respiratory system, rather than through the mucous membranes of the eyes. Our results confirm the findings of Gobba et al (18), who showed a similar linear relation for 73 glassreinforced plastics workers who did not wear masks during styrene exposure (38). 
Table 6. Visual symptoms according to the styrene exposure measurement (end-shift urinary mandelic acid or environmental styrene), adjusted for age and alcohol consumption. (OR = odds ratio, $95 \% \mathrm{Cl}=95 \%$ confidence interval)

\begin{tabular}{|c|c|c|c|c|c|c|}
\hline & \multicolumn{2}{|c|}{ Acute eye irritation } & \multicolumn{2}{|c|}{ Tearing } & \multicolumn{2}{|c|}{ Blurred vision } \\
\hline & OR & $95 \% \mathrm{Cl}$ & OR & $95 \% \mathrm{Cl}$ & OR & $95 \% \mathrm{Cl}$ \\
\hline $\begin{array}{l}\text { Age (years) } \\
\text { Alcohol consumption }\left(g \cdot \text { week }^{-1}\right) \\
\text { Mandelic acida }\left(\mathrm{mmol} \cdot \mathrm{mmol}^{-} \text {creatinine }^{-1}\right)\end{array}$ & $\begin{array}{l}0.95 \\
0.97 \\
5.50\end{array}$ & $\begin{array}{l}0.89-1.02 \\
0.77-1.23 \\
1.28-23.67\end{array}$ & $\begin{array}{l}0.98 \\
1.07 \\
4.73\end{array}$ & $\begin{array}{l}0.33-1.06 \\
0.82-1.39 \\
1.07-20.87\end{array}$ & $\begin{array}{l}0.91 \\
1.03 \\
6.47\end{array}$ & $\begin{array}{l}0.88-0.99 \\
0.80-1.29 \\
1.43-29.28\end{array}$ \\
\hline $\begin{array}{l}\text { Age (years) } \\
\text { Alcohol consumption }\left(g \cdot \text { week }^{-1}\right) \\
\text { Styrene }{ }^{b}\left(\mathrm{mg} \cdot \mathrm{m}^{-3}\right)\end{array}$ & $\begin{array}{l}0.96 \\
1.00 \\
1.53\end{array}$ & $\begin{array}{l}0.90-1.03 \\
0.79-1.26 \\
1.09-2.14\end{array}$ & $\begin{array}{l}0.99 \\
1.08 \\
1.36\end{array}$ & $\begin{array}{l}0.92-1.05 \\
0.83-1.41 \\
0.95-1.95\end{array}$ & $\begin{array}{l}0.92 \\
1.04 \\
1.37\end{array}$ & $\begin{array}{l}0.85-0.99 \\
0.81-1.32 \\
0.98-1.93\end{array}$ \\
\hline
\end{tabular}

a End-shift urinary measurement.

- Mean environmental styrene sampled on an 8-h workshift.

The chromatic localization (blue-yellow or red-green loss) of acquired dyschromatopsia is thought to be an indication of the area of neural damage. The majority of the subjects of this study, like those of Gobba et al (18), displayed deficits in the blue-yellow axis. This type of loss may reflect a change in the external retinal layer or change in the cornea (39) and may represent a first step in the progressive deterioration of the neurooptic pathway if organic solvent exposure continues (40).

Acquired dyschromatopsia in association with organic solvent exposure may result from an effect on the liposoluble fraction of the cones (41). However, progressive deterioration of color vision may possibly reflect a specific action of styrene or its metabolites (perhaps an interaction with ganglionaire cell receptivity) (42). In this case, the effect of styrene exposure on dopaminergic modulation may possibly interfere with the response modulation of retinian horizontal cell light. An elevation of dopamine may induce effects on the visual system. The horizontal cells induce the formation of electrical coupling between adjacent horizontal and receptor cells. The release of dopamine by the interplexiform cells induces a decrease in horizontal cell efficiency and therefore produces lateral inhibition. We postulate that the dopamine decrease alters the balance of center and surround responses and may explain effects on vision.

Like Fallas et al (29), we observed differences in contrast sensitivity. Workers with a higher end-shift concentration of urinary mandelic acid had poorer contrast vision in the higher frequencies when compared with the others. These results may reflect changes in ocular structure or in neurooptic transmission. Since every worker under study had good near visual acuity, as measured by high contrast standard visual acuity charts, the observed differences reflect possible changes in neurooptic transmission rather than ocular deficits (43).

The expected increase in the chromatic confusion index with age was observed in this population of workers (44). Age-related loss of color vision may result from changes in the lens or the macula (45). Other studies have demonstrated a dose relation between alcohol consumption and color vision loss (46). This effect on color vision, as with other solvents, may come from interference with the neurooptic pathway. However, in the present study, a positive significant relation was observed between alcohol consumption and the color confusion index determined for the best eye.

The average color confusion index computed with individual measurements from each eye has been used to characterize chromatic discrimination (18, 47-48). However, since differences were observed between the best and the worst eyes and because acquired dyschromatopsia can be monocular or involved unequally in the two eyes (34), the results of each person were split, and the analyses were repeated. Similar relations were observed for the two eyes taken separately and the environmental styrene exposure level for those who did not wear a mask. A greater relation was obtained for the index computed for the best eye of each worker, whereas that of the worst eye was similar to the average index.

The workers with higher styrene exposure or with higher urinary mandelic acid levels reported eye irritation, tearing, or blurred vision more frequently than the others. Styrene may have a local effect on the eye or on the nervous system.

These findings indicate that the Lanthony D-15 hue desaturated color vision panel is able to detect early effects associated with styrene exposure. It would be of interest to develop other visual tests, more related to retinal dopaminergic modulation, to help to determine the underlying mechanism.

\section{Acknowledgments}

We are grateful to the workers and services who participated in this study.

This study was supported by a grant from the Quebec Institute for Research in Occupational Health and Safety (IRSST) (grant N/D RS-89-03). 


\section{References}

1. National Institute for Occupational Safety and Health (NIOSH). Program plan by program areas for fiscal year. Washington (DC): US Government Printing Office 1983. DHHS publication, no NIOSH 83-102.

2. Wigaeus E, Löf A, Bjurström R, Byfält Nordqvist, M. Exposure to styrene: uptake, distribution, metabolism and elimination in man. Scand J Work Environ Health 1983;9:479-88.

3. Berode M, Droz PO, Guillemin M. Human exposure to styrene VI: percutaneous absorption in human volunteers. Int Arch Occup Environ Health 1985;55:531-6.

4. Engström J, Åstrand I, Wigaeus E. Exposure to styrene in a polymerization plant: uptake in the organism and concentration in the subcutaneous adipose tissue. Scand J Work Environ Health 1978;4:324 -9.

5. Bardodej Z, Bardodejova E. Biotransformation of ethyl benzene, styrene and alpha-methylstyrene in man. Am Ind Hyg Assoc J 1970;31:206-9.

6. American Conference of Governmental Industrial Hygienists (ACGIH). 1991-1992 threshold limit values and biological exposure indices. Cincinnati (OH): ACGIH, 1992.

7. Flodin U, Ekberg K, Andersson L. Neuropsychiatric effects of low exposure to styrene. Br J Ind Med 1989;46:805-8.

8. Lilis R, Lorimer WV, Diamond S, Selikoff IJ. Neurotoxicity of styrene in production and polymerization workers. Environ Res 1978;15:133-8.

9. Härkönen H. Relationship of symptoms to occupational styrene exposure and to the findings of electroencephalographic and psychological examinations. Int Arch Occup Environ Health 1977;40:231 $\rightarrow$.

10. Rosén I, Haeger-Aronsen B, Rehnström S, Welinder H. Neurophysiological observations after chronic styrene exposure. Scand J Work Environ Health 1978;4 suppl 2:184-94.

11. Seppäläinen AM. Neurotoxicity of styrene in occupational and experimental exposure. Scand J Work Environ Health $1978 ; 4(2): 181-3$.

12. Seppäläinen $\mathrm{AM}$, Härkönen $\mathrm{H}$. Neurophysiological findings among workers occupationally exposed to styrene. Scand J Work Environ Health 1976;3:140-6.

13. Cherry N, Waldron HA, Wells GG, Wilkinson RT, Wilson HK, Jones S. An investigation of the acute behavioural effects of styrene on factory workers. Br J Ind Med 1980;37:23440.

14. Cherry N, Rodgers B, Venables H, Waldron HA, Wells GG. Acute behavioural effects of styrene exposure: a further analysis. Br J Ind Med 1981;38:346-50.

15. Götell $P$, Axelson $O$, Lindelöf $B$. Field studies on human styrene exposure. Work Environ Health 1972;9(2):76-83.

16. Lindström $\mathrm{K}$, Härkönen $\mathrm{H}$, Hernberg $\mathrm{S}$. Disturbances in psychological functions of workers occupationally exposed to styrene. Scand J Work Environ Health 1976;3:129-39.

17. Muijser H, Hoogendijk EMG, Hooisma J. The effects of occupational exposure to styrene on high-frequency hearing, thresholds. Toxicology 1988;49(2):331-40.

18. Gobba F, Galassi C, Imbriani M, Ghittori S, Candela S, Cavalleri A. Acquired dyschromatopsia among styrene-exposed workers. J Occup Med 1991;33:761—5.

19. Fallas C, Fallas J, Maslard P, Dally S. Subclinical impairment of colour vision among workers exposed to styrene. $\mathrm{Br} \mathrm{J}$ Ind Med 1992;49(10):679-82.

20. Alieva ZA, Sultanov M, Mirzoev TA. Reduced acuity of color perception resulting from exposure to styrene and tetrachloroethylene vapours. Gig Tr Prof Zabol 1985;2:11-3.
21. Katoh T, Higashi K, Inoue N. Sub-chronic effects of styrene and styrene oxide on lipid peroxidation and the metabolism of glutathione in the rat liver and brain. J Toxicol Sci 1989;14:19.

22. Agrawal AK, Srivastava SP, Seth PK. Effect of styrene on dopamine receptors. Bull Env Contam Toxicol 1982;29:4003.

23. Mutti A, Romanelli A, Falzoi M, Lucertini S, Franchini I. Styrene metabolism and striatal dopamine depletion in rabbits. Arch Toxicol 1985;8:447-50.

24. Romanelli A, Falzoi M, Mutti A, Bergamaschi E, Franchini I. Effects of some monocyclic aromatic solvents and their metabolites on brain dopamine in rabbits. J Appl Toxicol 1986; $6(6): 431-5$.

25. Arfini GA, Mutti A, Vescovi P, Ferroni C, Ferrari M, Giaroli $C$ et al. Impaired dopaminergic modulation of pituitary secretion in workers. J Occup Med 1987;29:826-30.

26. Mutti A, Vescovi PP, Falzoi M, Arfini G, Valenti G, Franchini I. Neuroendocrine effects of styrene on occupationally exposed workers. Scand J Work Environ Health 1984;10:2258.

27. Mutti A, Falzoi M, Romanelli A, Bocchi MC, Ferroni C, Franchini I. Brain dopamine as a target for solvent toxicity: effects of some monocyclic aromatic hydrocarbons. Toxicology 1988;49:77-82.

28. Dowling JE. Functional and pharmacological organization of the retina: dopamine, interplexiform cells, and neuromodulation. In: Dowling JE, editor. Vision and the brain. Raven (NY): The Organization of the Central Visual System, 1990.

29. Fallas C, Roquelaure Y, Fallas J, Dally S. Influence de l'exposition au styrène sur le systeme nerveux central, la vision des couleurs et la perception des contrastes. Archives Mal Prof Med Trav Séc Soc 1991;52:5.

30. Johnson BL. Prevention of neurotoxic illness in working populations. Chichester (England): John Wiley \& Sons, 1987: $169-214$

31. Enquête Santé Québec. Et la santé ça va? Québec: Editeur officiel du gouvernement du Québec, 1988.

32. Institut de recherche en santé et en sécurité du travail du Québec (IRSST). Analyse du styrène dans l'air: méthode analytique 31-1. Montréal: IRSST, 1990.

33. Institut de recherche en santé et en sécurité du travail du Québec (IRSST). Détermination de l'acide mandélique dans l'urine: méthode analytique 106-1. Montréal: IRSST, 1990.

34. Institut de recherche en santé et en securité du travail du Québec (IRSST). Détermination de la créatinine urinaire: méthode analytique 163-1. Montréal: IRSST, 1989.

35. Hart WM. Acquired dyschromatopsias. Sur Ophthalmol 1987;32:10-28.

36. Bowman KJ. A method for quantitative scoring of the Farnsworth panel D-15. Acta Ophthalmol 1982;60:907-16.

37. Mäntyjärvi MI, Autere MH, Silvennoinen AM, Myöhänen T. Observation on the use of three different contrast sensitivity tests in children and young adults. J Pediatr Ophthalmol Strabismus 1989;26:113-9.

38. Truchon G, Ostiguy C, Drolet D, Mergler D, Campagna D, Bélanger $\mathrm{S}$, et al. Surveillance des effets neurotoxiques de l'exposition au styrène en milieu de travail I. evaluation environnementale et surveillance biologique. Trav Sant 1992;8: $11-4$.

39. Verriest $F$. On acquired deficiency of colour vision with special reference to its detection and classification by means of the test of Farnsworth. Vision Res 1961;1:201-19.

40. Mergler D. Color vision loss: a sensitive indicator of the 
severity of optic neuropathy. In: Johnson BL, Anger WK. Durao A, Xintras C, editors. Advances in neurobehavioral toxicology: applications in environmental and occupational health. Chelsea, England: Lewis, 1990.

41. Raitta C, Seppäläinen AM, Huuskonen MS. N-hexane maculopathy in industrial workers. Graef Archiv Klin Exp 1978; 209:99-110.

42. Raitta C, Teir H, Tolonen M, Nurminen M, Helpiö E, Malmström S. Impaired color discrimination among viscose rayon workers exposed to carbon disulfide. J Occup Med 1981;3(23): $189-92$.

43. Drucker MD, Savino PJ, Sergott RC, Bosley TM, Schatz NJ, Kubilis PS. Low-contrast letter charts to detect subtle neuropathies. Am J Ophthalmol 1988;105:141-5.

44. Helve J, Krause W. The influence of age on the panel D-15 colour vision test. Acta Ophthalmol 1972;50:896-900
45. Pokorny J, Smith VC, Verriest G, Pinkers AJ. Congenital and acquired colour vision defects. New York (NY): Grune and Stratton, 1979.

46. Mergler D, Blain L, Lemaire J, Lalande F. Colour vision impairment and alcohol consumption. Neurotoxicol Teratol $1988 ; 10: 255-60$.

47. Mergler D, Blain L. Assessing color vision loss among solvent-exposed workers. Am J Ind Med 1987;12:195-203.

48. Legault-Bélanger $S$, Bachand $M$, Bédard S, Brabant $C$, de Grosbois S, Mergler D. Perte de discrimination chromatique chez des travailleurs soumis à une exposition complexe et variable aux solvants organiques. Arch Mal Prof Med Sec Soc 1988;49: $475-82$

Received for publication: 1 August 1994 